\title{
Role and Importance of Technological Credits in Financing of Innovative Investments by Small and Medium-sized Enterprises in Poland and Lesser Poland
}

\section{Introduction}

Contemporary economy is based on innovation as it is reflected in various fields of operation of small and medium-sized enterprises, particularly as they constitute the core of not only Polish but also the European economy.

The concept of innovation in the economy was introduced by J. Schumpeter. The concept in his approach is very broad and includes all changes of a technical and organizational nature that may take place in business units. Innovation was also defined by P. Drucker. In his opinion, innovations permeate all areas of business. These may include product changes, changes in marketing, in organization and management methods [1].

Similarly, a broad approach of innovation was provided in the Oslo Manual. It is a document issued by the Organisation for Economic Co-operation and Development (OECD), which contains a discussion on the methods of collecting and interpreting innovation indicators. According to the Oslo Manual an innovation is the implementation of a new or significantly improved product (good or service), or process, a new marketing method, or a new organisational method in business practices, workplace organisation or external relations.

As the EU market expands, increasing attention is paid to innovation, thus to competitiveness of small and medium-sized enterprises (SMEs). Polish SMEs have faced problems obtaining third-party capital to finance their innovative activities that require high capital expenditure since the very beginning of the economic

\footnotetext{
* AGH University of Science and Technology, Faculty of Management
} 
transformation in Poland. As a result, few businesses invest in new technologies, innovative products, marketing or organisational solutions. Entrepreneurs cite the following main reasons for scant investments: difficulties obtaining external capital and insufficient demand for innovative products in the Polish market. In effect, as globalisation has proceeded, entrepreneurs began to fear for their competitive status in the market. They became afraid they would be pushed out of the market by EU enterprises with stronger capital, better management and enhanced innovativeness. Due to such capital barriers that restrict more innovative investments by small and medium-sized enterprises in Poland, this paper attempts an assessment of the role of technological credit in financing of investments by SMEs in Poland and Lesser Poland. Besides the available literature, empirical results generated by research into a group of Polish SMEs by the Polish Confederation of Private Employers 'Lewiatan', the Polish Agency for Enterprise Development (PARP), the Department of Market Forecasting and Analyses with the Economy Ministry, as well as the author's own research into SMEs in Lesser Poland.

\section{Financing of innovative activities by Polish SMEs in 1999-2011}

23\% of entrepreneurs surveyed by the Department of Market Forecasting and Analyses with the Economy Ministry stated that they engaged in innovative activities in the first half of 2011. Its report implies medium-sized enterprises run by university graduates tend to pursue such activities more often (Table 1).

Table 1

Percentage of small and medium-sized enterprises introducing innovations in 2011, broken down by company size

\begin{tabular}{|l|c|}
\hline \multicolumn{1}{|c|}{ Enterprise size } & Percentage of enterprises that introduced innovations \\
\hline Micro & 20 \\
\hline Small & 28 \\
\hline Medium & 43 \\
\hline
\end{tabular}

Source: the author's own compilation based on: [9]

In 2003-2008, investment spending of the enterprises under analysis climbed steadily. In 2003, entrepreneurs invested PLN 37 bln while in 2008 it was PLN $71 \mathrm{bln}$. Investment expenditure dropped by more than PLN 2 bln in the following year (2009), possibly a symptom of a partial block on investment activities due to the 2008 crisis. The results are presented in Table 2 . 
Role and Importance of Technological Credits...

Table 2

Capital expenditures of the Polish SME sector in total PLN bn in 2003-2009

\begin{tabular}{|c|c|}
\hline Years & Capital expenditures in PLN bn \\
\hline 2003 & 37.0 \\
\hline 2004 & 45.0 \\
\hline 2005 & 44.2 \\
\hline 2006 & 55.1 \\
\hline 2007 & 68.9 \\
\hline 2008 & 71.3 \\
\hline 2009 & 69.1 \\
\hline
\end{tabular}

Source: [6]

When investment spending as dependent on company size is analysed, one can note that most investment operations (more than $20 \%$ ) were initiated by medium-sized enterprises, followed by micro businesses (15\%) and small enterprises (Table 3).

Table 3

The structure of investment in the SME sector in 2009

\begin{tabular}{|l|c|}
\hline \multicolumn{1}{|c|}{ Enterprise size } & Investment in\% of SMEs \\
\hline Medium & $21.4 \%$ \\
\hline Small & $11.4 \%$ \\
\hline Micro & $15.2 \%$ \\
\hline
\end{tabular}

Source: $[6,8]$

CEBOS research for 'Lewiatan' indicates that medium-sized enterprises decided to invest more than small and micro enterprises in 2010. Where small and medium-sized enterprises make new investment decisions, they normally desire to boost their manufacturing capacity (23.5\%). It was much rarer for an entrepreneur to invest into research and development $(10.4 \%)$ or purchase of new technologies (11.7\%).

In the years 2010 and 2011 almost $70 \%$ of micro firms performed investment activities, as well as over $80 \%$ of small and $90 \%$ medium-sized companies. In the analysed period entrepreneurs predicted to maintain investments in the stable level or a slight decrease in them. The results are presented in Table 4 . 
Table 4

Investments that increase production capacity in the Polish SMEs in 2010-2011

\begin{tabular}{|c|c|c|c|c|c|c|}
\hline \multirow{3}{*}{ The level of investment } & \multicolumn{6}{|c|}{ Percentage of enterprises } \\
\hline & \multicolumn{2}{|c|}{ Micro } & \multicolumn{2}{|c|}{ Small } & \multicolumn{2}{|c|}{ Medium } \\
\hline & 2010 & 2011 & 2010 & 2011 & 2010 & 2011 \\
\hline Investing enterprises, total & 69.4 & 69.9 & 82.5 & 83.9 & 90.2 & 91.0 \\
\hline Increase & 20.4 & 18.0 & 32.7 & 23.7 & 43.5 & 35.4 \\
\hline Unchanged & 42.2 & 48.0 & 42.3 & 55.9 & 44.1 & 51.4 \\
\hline Decrease & 6.9 & 3.9 & 7.9 & 4.3 & 2.6 & 4.2 \\
\hline Not applicable & 30.6 & 30.1 & 17.5 & 16.1 & 9.8 & 9.0 \\
\hline
\end{tabular}

Source: the author's own compilation based on: [5, 6]

Regardless of whether entrepreneurs actually pursue investments or not, most of them (63\%) consider investments important and useful to building of a company's competitive status (Table 5).

Table 5

Entrepreneurs' opinion about the usefulness of business innovation activities in increasing the competitive position of enterprises

\begin{tabular}{|l|c|}
\hline \multicolumn{1}{|c|}{ The usefulness of innovation activities } & Percentage of SMEs \\
\hline Yes & 63.5 \\
\hline No & 15.5 \\
\hline Hard to say & 21.0 \\
\hline
\end{tabular}

Source: [6]

Tendency towards innovation is loosely dependent on the size of a business. Innovation is seen as important by more than $62 \%$ of micro entrepreneurs, $73 \%$ small and approx. $75 \%$ medium-sized enterprises [6].

The figures in Table 5 demonstrate entrepreneurs are aware of the need to invest into innovation but the limited access to external sources of financing is a barrier to investment operations.

In 1999-2011, own retained profits and capital contributed by owners are the principal sources of financing for SME investments. Bank crediting is the next source. More entrepreneurs took advantage of the latter source in 1999-2000 
Role and Importance of Technological Credits...

yet, in time, criteria for awarding credits were becoming increasingly stringent, mostly due to substantial rates of lost credit and the huge number of businesses active for less than a year. Entrepreneurs have been losing interest in leasing as well. The structure of investment financing by the Polish SME sector in 1999-2011 is shown in Table 6.

Table 6

Financing sources of the Polish SME sector in the years 1999-2011

\begin{tabular}{|l|c|c|r|r|r|r|r|r|r|}
\hline \multirow{2}{*}{\multicolumn{1}{|c|}{ Specification }} & \multicolumn{7}{|c|}{ The percentage of companies [in\%] } \\
\cline { 2 - 11 } & $\mathbf{2 0 0 0}$ & $\mathbf{2 0 0 4}$ & $\mathbf{2 0 0 5}$ & $\mathbf{2 0 0 6}$ & $\mathbf{2 0 0 7}$ & $\mathbf{2 0 0 8}$ & $\mathbf{2 0 0 9}$ & $\mathbf{2 0 1 0}$ & $\mathbf{2 0 1 1}$ \\
\hline $\begin{array}{l}\text { Shareholders' equity } \\
\text { including retained } \\
\text { earnings }\end{array}$ & 76 & 86 & 69.1 & 73.1 & 72.6 & 74.1 & 64.8 & 64 & 65 \\
\hline Bank loan & 38 & 14.2 & 16.6 & 12.7 & 17.4 & 12.8 & 17.7 & 10 & 12 \\
\hline Leasing & 24 & 12.6 & 10.5 & 9.0 & 6.9 & - & 8.3 & 8 & 11 \\
\hline EU Funds & 0 & 3.6 & 1.4 & 1.9 & 1.9 & 6.5 & 7.3 & - & 2 \\
\hline other & 0 & 0 & 2.4 & 3.3 & 1.2 & 2.9 & 1.9 & - & - \\
\hline
\end{tabular}

Source: the author's own compilation based on: $[3,6,9]$

The figures in Table 6 imply that sources of financing for SME investments did not change during the eleven years. It can only be observed that fewer entrepreneurs take advantage of bank credits or leasing.

A mere $6 \%$ of the companies that took bank credits in 2011 used investment credits; most obtained current account or working capital credits (Table 7).

Table 7

The share of enterprises using various forms of bank loans in 2011

\begin{tabular}{|l|c|c|c|c|}
\hline \multirow{2}{*}{\multicolumn{1}{c|}{ Type of loan }} & \multicolumn{4}{|c|}{ The percentage enterprises that use bank loans } \\
\cline { 2 - 5 } & Micro & Small & Medium & Total \\
\hline Overdraft & 17 & 33 & 39 & 29.6 \\
\hline Working capital loan & 6 & 16 & 17 & 13 \\
\hline Investment loan & 3 & 13 & 20 & 12 \\
\hline Another type of loan & 2 & 2 & 2 & 2 \\
\hline
\end{tabular}

Source: the author's own compilation based on: [9] 
Every second business credit applicant was awarded of the credit they had requested. A majority of successful applications (as many as 78\%) were submitted by medium-sized enterprises, followed by small (62\%) and micro businesses (35\%) (Table 8).

Table 8

Assessment of conditions for obtaining bank loans and cooperation with banks on business development opportunities in the opinion of entrepreneurs in 2011

\begin{tabular}{|l|c|c|}
\hline \multirow{2}{*}{$\begin{array}{c}\text { Assessment of conditions } \\
\text { for obtaining bank loans } \\
\text { and cooperation with } \\
\text { banks }\end{array}$} & $\begin{array}{c}|c| \\
\text { Conditions for obtaining } \\
\text { bank loans }\end{array}$ & Cooperation with banks \\
\cline { 2 - 3 } & 24.1 & 26.2 \\
\hline Impediment & 27.4 & 37.1 \\
\hline No effect & 26.8 & 25.6 \\
\hline Facilitation & 20.5 & 10.7 \\
\hline Not applicable & 1.8 & 0.4 \\
\hline Hard to say & & \\
\hline
\end{tabular}

Source: [6]

Merely $27 \%$ of businesses took advantage of bank credit in 2011. Research published by 'Lewiatan' confirms the regularity that the larger an enterprise, the easier access to bank crediting it enjoys. Only $24 \%$ of micro entrepreneurs and more than $60 \%$ of medium-sized enterprises employed bank credits. The results are illustrated in Table 9.

Table 9

The percentage of SME entrepreneurs using / not using bank loans

\begin{tabular}{|l|c|c|}
\hline \multirow{2}{*}{ Enterprise size } & \multicolumn{2}{|c|}{$\begin{array}{c}\text { The percentage of SME entrepreneurs using / not using } \\
\text { bank loans }\end{array}$} \\
\cline { 2 - 3 } & Yes & No \\
\hline Total SME & 27.1 & 72.9 \\
\hline Medium & 62.2 & 37.8 \\
\hline Small & 43.5 & 56.5 \\
\hline Micro & 24.3 & 75.7 \\
\hline
\end{tabular}

Source: [6] 


\section{Technological credit as a specialist source of financing innovation in the Polish SME sector}

The foregoing section of this paper has shown that Polish SMEs implement relatively few innovative investments, chiefly due to the limited access to external sources of financing, including investment bank crediting. Technological credit, available as part of the Innovative Economy Operational Programme, Action 4.3. with a budget of $€ 336149$ 568, may be of assistance to solving this problem.

The credit is issued by Bank Gospodarstwa Krajowego pursuant to the Act on certain forms of support for innovative activities dated 29 July 2005 and is earmarked to finance technological investments, which the Act defines as:

- purchase of new technology, its implementation and the resultant manufacture of new or modernised products or provision of new or modernised services,

- implementation of an own new technology and the resultant manufacture of new or modernised products or provision of new or modernised services,

- intangible technological know-how, in particular, results of research and development which enables us to manufacture new or improved products or services and which has not been used worldwide for longer than 5 years [10].

The Act implies that credit financing may cover their own or third-party solutions characterised by high novelty value and below 5 years of global application.

SME entrepreneurs are clearly beneficiaries of such funds as the technological credit cannot finance:

- large investments with spending in excess of the Polish zloty equivalent of $€$ $50 \mathrm{~m}$,

- investments in iron and steel metallurgy, synthetic fibres, coal mining and fisheries,

- investments related to the manufacture, processing and launching of products specified in Appendix 1 to the Treaty establishing the European Community (i.e. products of animal and plant origin including meat, fish, dairy, fruit, vegetables, fats, sugar, alcohol, tobacco, flax, hemp, etc.).

Credit may be provided for up to 72 months, though a 12-month grace in its repayment is possible. The amount of technological credit cannot exceed $€ 2 \mathrm{MM}$.

Technological credit is essentially a form of investment credit provided at arm's length conditions, which means that enterprises must demonstrate their financial liquidity and provide credit collateral. The rate of interest may not be 
greater than the average rate on the remaining investment credits awarded by the lending bank.

Its terms, especially commissions and fees, cannot be worse that those the bank offers in connection with other investment credits [10]. It differs from a traditional investment credit, however, in the so-called technological premium, that is, redemption of its part. A maximum premium may reach PLN 4 MM. In most Polish regions, it amounts to $70 \%$ for micro and small businesses and $60 \%$ for medium-sized enterprises. In the case of 'richer' regions, e.g. Mazovian, the limits are reduced to: $50 \%$ for micro and small businesses and $40 \%$ for medium-sized enterprises.

In practice, a part of this redemption is repaid with public resources. Until November 2010, this redemption had been conditional on the borrower spending technological investments on:

- purchase of new or second-hand fixed assets at arm's length conditions,

- extension or modernisation of the existing fixed assets,

- preliminary work, studies, expert opinions, concepts, engineering designs,

- purchase of intangible assets: patents, licences, unpatented technical, technological or management organisation know-how [11].

To prevent credit cancellations to entrepreneurs who have failed to make appropriate use of the funding, levels of the technological premium are dependent on sales volumes of goods and services generated by the implementation of such innovations. Thus, benefits could only be derived from the technological credit if a project was started and began to generate revenue. This requirement proves a substantial barrier to entrepreneurs, however, who claimed to be discouraged from using this source.

176 applications for financing had been submitted to BGK until 15 February 2010. The value of technological premiums requested reached approx. 287.5 million PLN 56 projects were approved and technological premiums of 98.6 million PLN were formally promised. 44 financing agreements were signed at a sum of 80.9 million PLN. A total of more than 1.200 million PLN remained to be consumed as part of action 4.3 Technological credit PO IG as of 15 February 2010, which the Ministry believed to be proof of poor utilisation of the resources.

Entrepreneurs cited the following issues as some other of the greatest drawbacks of technological credit:

- the support is calculated according to only that eligible expenditure which will be financed with a technological credit, not to the overall eligible expenditure (which applies to other EU-funded SME instruments);

- an implemented new technology must materialise as industrial property rights or research and development services. The patenting process is time- 
consuming and a new technology often loses its novelty value after its completion;

- an entrepreneur could request premium payment only after a specific sales level of goods or services produced by means of the new technology has been reached, not promptly at the end of a technological investment.

These opinions encouraged the Council of Ministers to amend the Act on 23 November 2010. Key changes allowed for support of unpatented know-how. As a result, an entrepreneur will find it far easier to comply with the formal requirements of an implemented technology and the ratio of approved applications should rise dramatically ( $44 \%$ had been accepted by 2010 while legislators estimate it should grow to $75 \%$ after the amendment). A variation to the method of computing the technological premium - not only on the basis of spending financed with technological credits but also of the entire eligible expenditure - is another major shift. Intensity of the support and average values of technological premium payments should climb as a result. The same concern is addressed by yet another change - cost of land purchase (to a maximum of $10 \%$ ), construction of buildings and structures, and costs of consulting services will be treated as part of the eligible expenditure. Consequently, the support can now be earmarked for projects where new technologies must be incorporated in new facilities. Investment processes can be commenced earlier as technological investments can now begin after a financing application is filed with BGK, not after a promissory note is executed, which was the case before. A Premium can also be paid promptly after the correct completion of a technological investment without the need to document sales of goods and services produced by means of new technologies.

Numbers of applications rocketed after the amendment of 23 November 2010. The technological credit budget for the years $2007-2013$ is $€ 336.1 \mathrm{~m}$, with PLN 278.2m distributed in June 2011. In 2011 alone, BGK received 146 applications for a total sum of PLN 420.7MM, with 103 applications approved for funding of nearly PLN 186MM (a mere 13.8\% of planned allocation). Agreements were concluded with 74 beneficiaries (that is, by nearly $100 \%$ more than before the amendment of 2010) providing for PLN 131.6MM (9.75\%) and PLN 14.3MM (merely $1.06 \%$ of the anticipated allocation) remitted to bank accounts of the beneficiaries.

Technological credits can finance investment undertakings pursued by enterprises in a variety of sectors and for diverse purposes, which is demonstrated by the examples in Table 10. It is difficult to determine which business types or sectors were most eager to take advantage of technological crediting as similar numbers of applications were presented by the individual sectors. No economic sector prevails over others and objects vary widely - from construction to IT and telecommunications, and food industry [12]. 
Table 10

Examples of projects where investments have been funded with technological crediting

\begin{tabular}{|c|c|c|}
\hline Name of company & Aim of project & $\begin{array}{l}\text { Amount of } \\
\text { financing }\end{array}$ \\
\hline $\begin{array}{l}\text { Poland Solution Center, Lodz } \\
\text { branch of Transition Techno- } \\
\text { logies S.A. of Warsaw, supplier } \\
\text { of IT solutions to energy and } \\
\text { gas markets }\end{array}$ & $\begin{array}{l}\text { ITIL Link - improvement of service } \\
\text { and IT process management servi- } \\
\text { ces using ITIL v3 standard. }\end{array}$ & PLN $105 \mathrm{~K}$ \\
\hline $\begin{array}{l}\text { Poland Solution Center Lodz } \\
\text { branch of Transition Techno- } \\
\text { logies S.A. of Warsaw, supplier } \\
\text { of IT solutions to energy and } \\
\text { gas markets }\end{array}$ & $\begin{array}{l}\text { Implementation of an immunolo- } \\
\text { gical industrial process optimiser } \\
\text { SILO II }\end{array}$ & PLN 166.4 K \\
\hline $\begin{array}{l}\text { MGGP Aero, provider of air } \\
\text { surveying services }\end{array}$ & $\begin{array}{l}\text { Air Teledetection Platform, an } \\
\text { appropriately converted plane } \\
\text { including sensors. An air laser } \\
\text { scanner (LiDAR), or a high- } \\
\text {-efficiency ranger that emits pulses } \\
\text { and accurately measures land, was } \\
\text { purchased, among other items }\end{array}$ & PLN $1.8 \mathrm{~m}$ \\
\hline Ekotech Sp. z o.o. & $\begin{array}{l}\text { Purchase and start-up of a mobile } \\
\text { installation producing mineral } \\
\text { hydraulic binders based on energy } \\
\text { sector waste }\end{array}$ & PLN $594 \mathrm{~K}$ \\
\hline $\begin{array}{l}\text { Przedsiębiorstwo Wielobran- } \\
\text { żowe Marek Mackiewicz }\end{array}$ & $\begin{array}{l}\text { Implementation of a processing } \\
\text { innovation in manufacture of } \\
\text { industrial concrete }\end{array}$ & PLN $2462 \mathrm{~K}$ \\
\hline Internet Media Services SA & $\begin{array}{l}\text { Implementation of a state-of-the- } \\
\text {-art Videomarketing System Digital } \\
\text { Signage Premium in leading shop- } \\
\text { ping arcades }\end{array}$ & PLN $1379 \mathrm{~K}$ \\
\hline
\end{tabular}

Source: the author's own compilation based on figures published at [12]

It can be said, therefore, that the 2010 amendment to the 2005 Act on certain forms of support for innovative activities made the credit a more accessible source of financing for innovative activities in the Polish SME sector. It is a unique combination of a standard investment credit (from commercial banks) and EU subsidies of up to PLN 4MM (as a technological premium), thus can facilitate innovation financing in the Polish SMEs. 


\section{Financing for innovative activities of Lesser Poland microbusinesses in 2009-2011}

The preceding sections of this paper have demonstrated that Polish SMEs have limited access to external sources of financing. This part of the article will present the author's own research among Lesser Poland entrepreneurs who applied for EU funding as part of action 6.2. 'Become a Lesser Poland entrepreneur' in 2009-2010 when Poland joined the EU and funding applications became possible.*

Among Lesser Poland microbusinesses, like all Polish SMEs, retained profit and owners' capital were the principal sources of financing both in 2009 and 2010. Additionally, $6 \%$ of the respondents obtained venture capital in 2009 , which was not the case in 2010 (Table 11)

Table 11

Financing sources of investments in Lesser Poland micro enterprises in 2009-2010

\begin{tabular}{|c|c|c|}
\hline \multirow{2}{*}{ Financing sources } & \multicolumn{2}{|c|}{ The percentage of micro enterprises using equity [\%] } \\
\hline & 2009 & 2010 \\
\hline Profit & 52 & 71 \\
\hline Owner's capital & 42 & 75 \\
\hline Venture capital & 6 & 0 \\
\hline Loan & 32 & 14 \\
\hline Leasing & 29 & 14 \\
\hline Factoring & 0 & 0 \\
\hline Franchising & 0 & 0 \\
\hline EU Funds & 84 & 96 \\
\hline Surety & 3 & 0 \\
\hline Loan funds & 3 & 0 \\
\hline Business incubator & 3 & 0 \\
\hline other & 0 & 0 \\
\hline
\end{tabular}

Source: [3]

* The sample is further described in [2] 
The figures in Table 11 show that entrepreneurs took advantage not only of their own capital but also of EU resources, though it is due to the unique nature of this particular population. Few of them received bank credits, like all Polish SMEs not covered in the EU project. Scarce entrepreneurs received credit guarantees from credit guarantee funds or used the assistance of business incubators in both 2009 and 2010. Only three sources of third-party investment financing were utilised: bank credits, leasing, and EU resources.

Considerably (18 percentage points) fewer companies employed bank credits, 15 percentage points fewer funded their investments with leasing in 2010 as compared to 2009 . None took advantage of venture capital, credit guarantee funds funding or aid of business incubators.

Due to the problems of obtaining bank credits, some entrepreneurs financed their planned investments with private bank crediting which was then allocated to investments. The research results are illustrated in Table 12.

Table 12

The percentage of entrepreneurs making investments from bank loans to individuals in 2009-2010

\begin{tabular}{|l|c|c|}
\hline \multirow{2}{*}{$\begin{array}{c}\text { The use of bank loans } \\
\text { to individuals }\end{array}$} & \multicolumn{2}{c|}{$\begin{array}{c}\text { The percentage of enterprises using loans } \\
\text { to individuals in }\end{array}$} \\
\cline { 2 - 3 } & 2009 & $\mathbf{2 0 1 0}$ \\
\hline Use & 6 & 4 \\
\hline Do not use & 69 & 86 \\
\hline Intention to use & 25 & 11 \\
\hline
\end{tabular}

Source: Duda J. [4]

Table 12 figures indicate $2 \%$ fewer companies used this form of crediting and 14\% fewer declared their intention to obtain such funding in 2010.

In January 2012, the author began a new survey research project concerning sources of financing for innovative activities of Lesser Poland enterprises. The target group comprised of 65 enterprises. Results of a pilot study into 15 Lesser Poland SMEs will be discussed in the following sections, though. The research population is so limited because the work is in progress and the presentation of partial results is not intended to lead to conclusions regarding the entire population but only to indicate new trends apparent in 2011.

Like in the case of the entire Polish small and medium-sized enterprise sector and the Lesser Poland microbusiness population analysed before, most of 
Role and Importance of Technological Credits...

these enterprises financed investments with their own capitals, including retained profits. The research results are presented in Table 13.

Table 13

Financing sources of investment in Lesser Poland SMEs in 2011

\begin{tabular}{|l|c|}
\hline \multicolumn{1}{|c|}{ Financing sources } & The percentage of micro enterprises using equity [\%] \\
\hline Owner's capital & 53 \\
\hline Retained earnings & 73 \\
\hline Venture capital & 0 \\
\hline Loan & 33 \\
\hline Leasing & 20 \\
\hline Factoring & 0 \\
\hline Franchising & 0 \\
\hline EU Funds & 33 \\
\hline Surety & 0 \\
\hline Loan funds & 0 \\
\hline Business incubator & 0 \\
\hline other & 0 \\
\hline
\end{tabular}

Source: the author's own compilation

Table 13 demonstrates that own capital, namely, retained profits and owners' capital surcharges, remain the chief source of funding in 2011 (73\%). (Above $50 \%)$ more entrepreneurs used bank credits (33\%) to fund their investments than the entire Polish SME sector. The same can be observed about leasing, employed by $20 \%$ of the Lesser Poland respondents, compared to $11 \%$ of all Polish SMEs in the same year. EU funds accounted for a significant share (33\%) of financing for investment activities.

Those entrepreneurs facing difficulties when trying to obtain bank credits for their investments have borrowed arranged for bank credits (13\%), with $27 \%$ declaring this intention in future. A majority (60\%) do not plan to resort to this form of investment financing, however (Fig. 1).

It appears that both groups of Lesser Poland enterprises faced difficulties obtaining bank credits and, consequently, some entrepreneurs have taken advantage of private bank crediting for investment purposes, or intend to do so. 


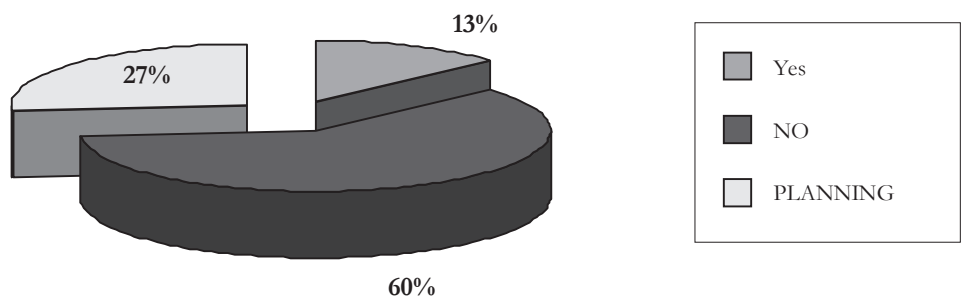

Figure 1. The percentage of SMEs in Lesser Poland using loans to individuals in 2012 to finance their investment activities.

Source: the author's own compilation.

The foregoing analysis also suggests that both Polish and Lesser Poland enterprises encounter problems when seeking external capital, including bank credits, therefore can resort to financing innovative activities by means of the technological credit described above.

\section{Conclusion}

Investing in innovative solutions is a challenge to all enterprises, in particular the SME sector, especially as it exhibits enhanced risk and financing requirements.

Results of the research discussed in this paper demonstrate that the Polish SMEs have for years faced difficulties obtaining third-party capital to finance their investment activities. Own capital, most frequently retained profits, have constituted the principal source of financing for eleven years now. The figures published by the Department of Market Forecasting and Analyses with the Economy Ministry indicate that $23 \%$ of the SMEs surveyed declared they engaged in innovative activities in 2011. Research clearly implies that the smaller an enterprise, the less willing it is to innovate. Nonetheless, investment expenditure gradually increased in 2003-2010 (Table 2). The limited extent of innovative investment projects is not a result of low entrepreneur awareness, as more than $63 \%$ consider such activities important and useful to enterprise development and building of its competitive position in the market (Table 5).

Entrepreneurs cited low demand for investments in the Polish market as the main reason for the absence of investment in innovations, chiefly because the purchasing decisions of customers in Poland are driven by prices, which does not encourage the launching of expensive innovative products. Barriers to access 
to funding are another difficulty. This is confirmed by research conducted by both 'Lewiatan' and PARP for the entire population of Polish SMEs and the author's own research in Lesser Poland.

Survey results presented in Table 6 show Polish SMEs employed only three sources of financing in the period from 1999 to 2011: own capitals, bank credits, and leasing. The share of businesses resorting to bank credit fell markedly in the period under analysis. In 2011, as many as $72 \%$ of Polish SMEs did not take advantage of bank credits (Table 9) since most bank require three years of crediting history and high collateral. To limit their risk, banks normally issue current account and working credits (Table 7), which prevents entrepreneurs from pursuing long-term investments. Lesser Poland's SMEs operate in similar circumstances. They also drew funding for their investments from three sources, namely: own capitals, bank credits, and leasing. Due to the unique nature of this population, most businesses obtained financing from EU funds. An analysis of the results indicates that, compared to the entire SME sector, more Lesser Poland entrepreneurs received bank credits though some used private bank crediting for investment purposes as they found it difficult to obtain long-term investment credits. It is for that reason that technological credit - combining the characteristics of a bank credit and EU funding as the technological premium can reach $60-70 \%$ of an investment's value - may prove of assistance to financing of innovative investments. Until 2010, entrepreneurs had complained against barriers to access to this source because, for instance, payment of a technological premium, that is, redemption of a part of the credit, could be requested only after an appropriate sales volume had been attained, new technologies had to be constituted as industrial property rights or research and development services, and support was computed on the basis of eligible costs. The Act on certain forms of support for innovative activities was amended on 23 November 2010 to abolish the barriers described above and make the credit a more enticing source of financing for innovative investments. This is proven by a dramatic rise in the share of approved applications for technological credits in 2011.

\section{References}

[1] Drucker P.F., On the Profession of Management, Harvard Business Scholl Press, Boston, 1998.

[2] Duda J., Decyzje inwestycyjne przedsiębiorstw polskich z sektora MSP, in: Prace Naukowe Uniwersytetu Ekonomicznego, Wydawnictwo Uniwersytetu Ekonomicznego, Wrocław, 2009.

[3] Duda J., Strategie finansowania dziatalności inwestycyjnej polskich MSP na rynku Unii Europejskiej, w: Strategie i determinanty wzrostu wartości 
przedsiębiorstwa, Zeszyty Naukowe Uniwersytetu Szczecińskiego nr 685, Finanse, Rynki Finansowe, Ubezpieczenia nr 46, Szczecin 2011.

[4] Duda J., Wplyw globalizacji na działalność finansowa $i$ inwestycyjna polskich MSP, w: Zarządzanie finansami. Wspótczesne wyzwania teorii i praktyki, Zeszyty Naukowe Uniwersytetu Szczecińskiego nr 640, Finanse, Rynki Finansowe, Ubezpieczenia nr 38, Szczecin 2011, s. 231-242.

[5] Europejski Program Modernizacji Polskich Firm, MSP pod lupq raport, PARP, Warszawa, 2011.

[6] Monitoring kondycji sektora MSP, PKPP Lewiatan, Warszawa 2004, 2005, 2006, 2007, 2009, 2010, 2011, 2012.

[7] Pietras P., Głodek P., Finansowanie przedsięwzięć innowacyjnych $w$ MSP, PARP, Warszawa, 2011.

[8] Pietras P., Głodek P., Finansowanie komercjalizacji technologii i przedsięwzięć innowacyjnych opartych na wiedzy, PARP, Warszawa 2011.

[9] Trendy rozwojowe sektora MSP $w$ ocenie przedsiębiorców $w$ pierwszej potowie 2011 roku, MG DPiA, nr 2/2012, Warszawa 2011.

[10] Ustawa o wspieraniu niektórych form dziatalności inwestycyjnej [Dz.U. Nr 179, poz 1484, art. 3.1].

[11] Witryna internetowa: www.bgk.com.pl.

[12] Witryna internetowa: www.pi.gov.pl. 